\title{
A Legal Perspective of Building Credibility System in China
}

\author{
Zhen Shu \\ College of Humanities, Xi' an Science and Technology University \\ 58 Yan Ta Road, Xi'an 710054, Shaanxi, China \\ E-mail: shuzhen369@126.com
}

Received: April 5, $2011 \quad$ Accepted: April 26, $2011 \quad$ doi:10.5539/ass.v7n8p183

\begin{abstract}
Credibility is an old yet modern topic. It has a particular significance in the current trend of market economy. However, China is facing a serious crisis of credibility nowadays. This paper proposes the suggestion of building credibility system in China from legal perspective.

Keywords: Credibility, Credibility right, Legislation

A man will not become mature without credibility; a country will go downhill without credibility. Credibility is an old yet modern, real yet eternal topic. The topic is old in that it is embodied in Confucius' ideas more than 5 thousand years ago; it is modern in that credit is the corner-stone for market economy and democracy and legal system. It is something that should be faced not only by transitional countries but also by all the countries which suffer from a series of economic scandals. It is eternal in that old systems are constantly challenged. With the development of science and technology, man's opinions need to be refreshed and new credibility systems need to be built and perfected. So long as human being exists, credibility will be an eternal topic.
\end{abstract}

\section{The Content of Credibility in Market Economy}

Credibility includes the following three aspects:

Firstly, it is related with culture and moral. If someone is honest and trustworthy, this person is regarded to be credible. Moreover, it also shows the credibility relationship between each other. From this point of view, credibility has a very long history because it is a traditional virtue in China for thousands of years.

Secondly, credibility refers to a kind of economical relationship. The development of credibility can't be separated from that of economy. The earliest bank is the temple bank before 3000 years B.C. At that time, people are highly respectful to the temples, in which they store their valuable items. The temples are very credible and they will return everything that anyone store there. And when the temples have any extra money or valuable items, they will lend it to any people who need it. Gradually, banks come into being. Therefore, bank and finance can't be separated from credibility.

Thirdly, credibility refers to a kind of legal relationship. To some people, credibility itself is a kind of law. In fact, it is more than that. In most cases, credibility mainly depends on people's awareness and does not need any tough legal enforcement. It will rise to law only under certain conditions. That is to say, if the market players are not credible and disobey credibility, they will be punished by law in order to protect the investors. Only by this can social market economy operate orderly and normally.

From the above analysis, credibility is not only a personal problem but also a social relationship. It reflects cultural and moral, legal and economical relationship. Therefore, we can draw the conclusion that credibility is very important.

\section{Credibility Crisis and Its Source}

Based on the importance of credibility in market economy, credibility can be regarded as a kind of intangible capital. However, more and more people ignore this intangible capital which can actually bring great benefit. As a result, credibility crisis is very serious in economical society. Some of them make people very shocking. Missing of credibility is like a disease which spreads and involves many departments and fields, from all kinds of fraud to default, from the field of production and distribution to financial, educational and even medical department, from enterprises to listed companies, from individual to government

It is worth thinking how to understand the missing of credibility in China nowadays. 
Firstly, credibility crisis is a stage product as a result of economical change. After the reform of economical system in China, all the society experience unprecedented and profound changes. To many people, the only standard to measure social position and prestige and honor is wealth. Credibility seems insignificant in contrast to wealth. The most striking example is the common phenomenon that the debtors maliciously avoid debt but the creditors could do nothing.

Secondly, credibility crisis is the product of the unconfirming of some new economical relationship. With the development of economy, there are more new economical relationships coming into being, such as joint ventures, joint-stock relations, lease contract relations, labor relations employment, unemployment and unemployed relationship between the private self, the relationship between partnerships, etc. When new economical relationships are increasing rapidly, the legal systems cannot keep up with the pace, and therefore appear a bit lagged behind. The way of restraint beyond law becomes powerless. Under these circumstances, credibility has to give way to material benefit. Therefore, the missing and deficiency of legal norms is one of the reasons for the deterioration of credibility.

Finally, credibility crisis is also caused by the lacking of credibility evaluation and record-keeping system. Everyone's credibility is the accumulation of his own past. In order to accumulate credibility accurately and effectively, it is better to quantify it first. Because of the lacking of credibility evaluation and record-keeping system, the state of credibility of an enterprise is mainly evaluated by the number and size of the registered capital of enterprises. This evaluating method is full of risk in that the registered capital might be unreal and the size of an enterprise does not necessarily reflect its economic strength. Individual credibility is judged more subjectively in the case of lack of record.

Apparently, rebuilding social credibility is a necessary factor in realizing a harmonious society. All social systems should be legalized in market economy and law should play an important role in the rebuilding social credibility.

\section{Perfect the Legislation of Credibility and Increase the Pace of Credibility Construction}

The construction of credibility has just started in China. However, it has a long history in some developed countries in which the operating system has been scientific, standardized and legal. By reference to foreign experience combined with Chinese reality, the key to construct credibility lies in setting rules and systems and overcoming the dilemma that the construction of credibility has no law or system to abide by.

\subsection{Credibility is a kind of right}

In legal sense, credibility right refers to the right that natural persons, legal persons and other organizations have commitments beyond the practical ability and willingness to gain the trust level of social evaluation, and retention, use, income, credit and the exclusion of others to interfere in action. Credibility right, as an independent personality right, can be enjoyed by all natural and legal persons and used to safeguard their credit rights in social and economic activities. Meanwhile, the establishment of legal rights also means the existence of corresponding obligations. This obligation, on the one hand reflects any act of defamation of others' credit will be prohibited by law in social and economic activities; on the other hand, any departure from the norms of credit will be abandoned by society and orderly competition and may be subject to sanctions. For example, in the case of against the credit, natural and legal persons will be restricted or limited by the civil sanctions act, and even lose some corresponding civil rights to some extent and within a certain range. Only in this way can we build the social mechanism of constraints and coordination, so that the whole community will establish a sound market economic order on the basis of honesty and trustworthiness. This is the significance to establish credit right and protect legislation from legislative point of view. Therefore, setting rights of credit in the basic civil law will be effective in promoting awareness of social credit, and thus to facilitate transactions, improve efficiency, expand market size, and achieve the purpose of integration with the international market.

\subsection{We should strengthen to modify and improve the law guided by the principle of good faith, which is regarded} as "imperial provision"

The contract law first makes it clear that principle of good faith is regarded as the basic legal principles and further specifies it as legal rights and obligations of the parties, which will effectively punish acts of dishonesty to protect the interests of the trustworthy persons. The development of contract law provides a reference to revise and improve other laws. Legislators should be more consciously guided by the principle of good faith to modify the laws incompatible with the market economy and to enable more specific principle of good faith, such as the negotiable instruments law, the counter-unfair-competition law, the commercial bank law, etc. Therefore, honest and credit behavior will be more effectively protected and fraud and other acts contrary to the principle of good faith will be punished by legal means. 


\subsection{Appropriate laws and regulations should be established}

The collection of any credit-related data can not do without the supporting laws and regulations, particularly the construction of individual credit system. For example, personal savings deposits should be further implemented by real-name system, so that it will lay the foundation for personal credit system; a personal property declaration system should be established to ensure data integrity of personal property; basic personal accounts system should be established to ensure to initiate personal credit on time; a personal insolvency system that allows individuals to enter bankruptcy proceedings under certain conditions should be created to release the debtor exempted from the remaining debt and protect the well-functioning of personal credit system; a personal credit guarantees and insurance system should be established to distribute and share personal credit risk. In addition, to build personal credit system, it is necessary to have some supporting systems, such as a sound social security system, housing system, medical system, and so on.

\subsection{The openness and sharing of credit should be promoted}

The law is an effective protection to establish credit institutions. The banks should call for the laws and regulations about credit as soon as possible, define the relationship between the openness of data and the protection of personal privacy and business secrets so that the credit system will obtain the support and protection of national laws. According to China's current "Commercial Bank Law", "Anti-Unfair Competition Law", some credit information is prohibited to be open in the public or circulated as it involves personal privacy and commercial secrets. To establish a credit system, we must introduce relevant laws and regulations in advance to ensure the credit information opening up, that is, the entire procedure of credit data collecting, statistical processing, field verification, electronic data storage and commercial transmission according to law should be open.

\subsection{Punishing mechanism for bad credit should be established and improved}

A standard social credit system and punishing mechanism for bad credit should be established so as to constrain acts of dishonesty from legal aspect and provide system and legal protection for the raising of social credit level. On the one hand, we should ensure those who are credible able to get due return, on the other hand, those who are dishonest bear the costs caused by their behavior. Punishment for acts of dishonesty should be increased in the efforts to make those who are dishonest get deserved punishment, while other companies will see the cost of dishonesty, and thus attach great importance to integrity management awed by the majesty of the law. As a result, good deeds will be rewarded with good, evil with evil.

The law can pass unimpeded with the help of morality, and morality can be spread under the provision of law. With the improvement and perfect of the integrity of legal system, we have every reason to look forward to the return of the traditional virtues.

\section{References}

Huang, Yan. (2004). The Difficulties and Strategies on the Building and Integrity of the System of Social Credit. Journey of Direct Branch Under the Shanxi Provincial Committee Party School of CPR, (1).

Liu, Guoguang. (2005). Analysis and Forecast of China's Economic Situation. Beijing: Social Sciences Academic Press.

Zhou, Hanhua. (2002). Credibility and Law. Comparative Economic and Social Systems, (3).

Zhou, Yeliang. Suggestion on the Controlling of Social Credit Environment in China. FuJian Finance, (1).

Zuo, Weiqing. (2002). On the Obstacles and Consequences of the Development of Economy Based on Credit in China. Truth Seeking, (8). 